Jurnal Hukum Mimbar Justitia

Fakultas Hukum Universitas Suryakancana

Vol. 4 No. 2 - Desember 2018, hlm. 138-155.

ISSN: 2477-5681 (Cetak), ISSN: 2580-0906 (Online)

Open Access at: https://jurnal.unsur.ac.id/jmj

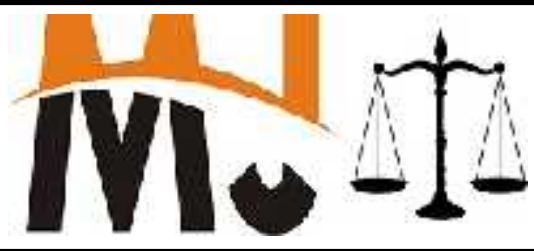

\title{
PENEGAKAN HUKUM TINDAK PIDANA POLITIK UANG PEMILIHAN KEPALA DAERAH DI PROVINSI BANTEN MENURUT UNDANG-UNDANG NOMOR 10 TAHUN 2016 TENTANG PEMILIHAN GUBERNUR, BUPATI DAN WALIKOTA
}

\author{
Asnawi \\ Universitas Bina Bangsa \\ Email : srgasnawi@gmail.com \\ dan \\ Aji Mulyana \\ Universitas Islam Bandung \\ Email : ajimulyana94@gmail.com
}

Masuk: September 2018 Penerimaan: Oktober 2018 Publikasi: Desember 2018

\begin{abstract}
ABSTRAK
Pemilihan Umum Kepala Daerah dan Wakil Kepala Daerah adalah Pemilihan Umum untuk memilih Kepala Daerah dan Wakil Kepala Daerah secara langsung dalam Negara Kesatuan Republik Indonesia berdasarkan Pancasila dan Undang-Undang Dasar Negara Republik Indonesia Tahun 1945. Pemilihan Kepala Daerah memiliki landasan filosofis yuridis Pasal 18 ayat (4) Undang-Undang Dasar Negara Republik Indonesia Tahun 1945. Pemilihan Kepala Daerah secara langsung dan serentak pertama kali dilakukan pada tahun 2015. Pilkada serentak selanjutnya dilaksanakan pada tahun 2017, salah satu wilayah yang melaksanakan adalah Provinsi Banten. Penelitian ini bertujuan untuk mengetahui ada tidaknya pelanggaran tindak pidana politik uang pemilihan kepala daerah menurut Undang-Undang Nomor 10 Tahun 2016 tentang Perubahan Kedua Atas Undang-Undang Nomor 1 Tahun 2015 Tentang Pemilihan Gubernur, Bupati dan Walikota Pemilihan Umum Anggota DPR, DPD, dan DPRD. Penelitian ini dilakukan dengan menggunakan metode pendekatan yuridis normatif dan yuridis empiris yaitu melakukan pendekatan yang dilakukan berdasarkan bahan hukum utama dengan cara menelaah peraturan perundang-undangan dan penelitian secara langsung di Badan Pengawas Pemilu Provinsi Banten. Berdasarkan hasil penelitian, pelanggaran yang dilaporkan Badan Pengawas Pemilu yaitu penyalahgunaan alat praga kampanye, kampanye terselubung dan Politik Uang.
\end{abstract}

Kata Kunci: Tindak Pidana; Politik Uang; Penegakan Hukum; Pilkada.

\section{ABSTRACT}

The elections of the head of the region and Deputy Head of the region are the elections to choose the head of the region and Deputy Head of the area directly within the Unitary State of the Republic of Indonesia based on Pancasila and the Constitution of 
the Republic of Indonesia The year 1945. The election of the head of the philosophical foundation of the juridical area has Article 18 paragraph (4) of the Constitution of the Republic of Indonesia Year 1945. The election of the head of the Region directly and simultaneously was first performed in the year 2015. Simultaneous elections were held next in 2017, one of the areas that carry out is the province of Banten. This research aims to find out whether there is a violation of criminal acts of political money election of the head of the region according to law No. 10 The Year 2016 on the second amendment in the law number 1 The Year 2015 About The Gubernatorial election, Governor and the Mayor elections of members of Parliament, DPD, and DPRD. This research was conducted by using the juridical normative approach method and empirical juridical approach that is performed based on the primary law materials by way of reviewing legislation and research direction in The Election Watchdog Agency Of Banten Province. Based on the results of the study, the reported violations of the election Watchdog Agency that is abuse of the tools praga campaign, veiled and Political campaign money.

Keywords: Crime; Law Enforcement; Money Politics; Elections.

\section{PENDAHULUAN}

Sejak dilakukannya perubahan UUD 1945, sistem ketatanegaraan Indonesia mengalami perkembangan, begitu pula terhadap studi Hukum Tata Negara sebagai keniscayaan dari reformasi. ${ }^{1}$ Studi hukum tata negara dan konstitusi semakin menarik ketika melihat kenyataan bahwa UUD 1945 pasca amandemen mengimplikasikan perubahan secara mendasar dalam sistem ketatanegaraan Indonesia,

1 Dedi Mulyadi dan M. Rendi Aridhayandi, 2015, Putusan Mahkamah Konstitusi Tentang Pemilu Serentak Dihubungkan Dengan Pencegahan Korupsi Politik, Jurnal Mimbar Hukum Justitia Fakultas Hukum Universitas Suryakancana, Vol. 1 No. 2 Desember, hlm. 534. termasuk struktur dan relasi kelembagaan negara. ${ }^{2}$

Salah satu dampak dari perubahan tersebut adalah perubahan sistem pemilihan Kepala Daerah dan Wakil Kepala Daerah yang dilakukan secara langsung. Perubahan ini penting untuk meletakan kembali kedaulatan berada ditangan rakyat, sehingga rakyat daerah khususnya memiliki peran dan kesempatan terlibat dalam pengambilan keputusan-keputusan di bidang penyelenggaraan pemerintahan daerah.

Pilkada secara langsung dapat diselenggarakan setelah terjadi perdebatan sengit mengenai

2 Martitah, 2013, Mahkamah Konstitusi (Dari Negative Legislature ke Positive Legislature), Konstitusi Press (Konpress), Jakarta, hlm. 2. 
Asnawi dan Aji Mulyana

Jurnal Hukum Mimbar Justitia

Vol. 4 No. 2 - Desember 2018

mekanismenya apakah dipilih secara langsung atau dipilih oleh DPR. Perdebatan ini pernah terjadi pada tahun 2005 namun mengemuka lagi pada tahun 2014. Landasan filosofis yuridis yang mendasari dinamika perdebatan Pemilukada adalah bunyi Pasal 18 ayat (4) Undang-Undang Dasar Negara Republik Indonesia Tahun 1945 yang mengamanatkan bahwa Gubernur, Bupati, dan Walikota masing-masing sebagai Kepala Pemerintah Daerah Propinsi, Kabupaten, dan Kota dipilih secara demokratis. Frasa "dipilih secara demokratis" ditafsirkan tidak berarti Kepala Daerah harus dipilih secara langsung namun dapat pula dipilih secara tidak langsung sepanjang prosesnya demokratis. Apabila dicermati, sesungguhnya ketentuan Pasal 18 ayat (4) UUD 1945 tersebut tidak menegaskan keharusan bahwa Gubernur, Bupati dan Walikota harus dipilih melalui suatu pemilihan yang dilaksanakan secara langsung. Akan tetapi, menurut Rozali Abdullah, oleh karena Daerah merupakan bagian tak terpisahkan dari Negara Republik Indonesia, maka dalam melakukan pemilihan kepala daerah dan wakil kepala daerah seharusnya sinkron dengan pemilihan presiden dan wakil presiden, yaitu melalui pemilihan langsung. ${ }^{3}$

Pilkada secara langsung pertama kali diselenggarakan pada bulan Juni 2005, yaitu sejak berlakunya UndangUndang Nomor 32 Tahun 2004 tentang Pemerintahan Daerah. Kemudian setelah keluarnya Undang-Undang Nomor 22 Tahun 2007 jo. UndangUndang Nomor 15 Tahun 2011 Tentang Penyelenggaraan Pemilihan Umum, Pasal 1 angka 4 yang menentukan bahwa "Pemilihan Umum Kepala Daerah dan Wakil Kepala Daerah adalah Pemilihan Umum untuk memilih

Kepala Daerah dan Wakil Kepala Daerah secara langsung dalam Negara Kesatuan Republik Indonesia berdasarkan Pancasila dan UndangUndang Dasar Negara Republik Indonesia Tahun 1945”. Sehingga secara resmi bernama Pemilihan Umum Kepala Daerah dan Wakil Kepala Daerah (PEMILUKADA).

Namun, pada tahun 2014 RUU Pilkada yang salah satu muatannya adalah pengembalian pemilihan Kepala

\footnotetext{
Rozali Abdullah, 2005, Pelaksanaan Otonomi Luas dengan Pemilihan Kepala Daerah Secara Langsung, Rajawali Pers, Jakarta, hlm. 53.
} 
Asnawi dan Aji Mulyana

Jurnal Hukum Mimbar Justitia

Vol. 4 No. 2 - Desember 2018

Daerah oleh DPRD (pemilu tidak langsung) berhasil disahkan pada tahun 2014. Ketika itu RUU Pilkada berhasil disahkan karena hadirnya dukungan mayoritas partai politik di DPR yakni dari Gerindra, PAN, Golkar, PPP, PKS, Demokrat. Tak pelak keputusan politik ini menjadi polemik dikalangan elit pemerintah, politisi, akademisi, dan masyarakat. RUU itu menjadi UndangUndang Republik Indonesia Nomor 22 Tahun 2014 Tentang Pemilihan Gubernur, Bupati, dan Walikota. Setelah terjadi perdebatan politik hingga muncul penolakan publik, maka pemerintah akhirnya mengeluarkan Peraturan Pemerintah Pengganti Undang-Undang Republik Indonesia Nomor 1 Tahun 2014 Tentang Pemilihan Gubernur, Bupati, Dan Walikota yang kemudian disusul dengan dikeluarkannya Undang-Undang Nomor 1 Tahun 2015 Tentang Penetapan Peraturan Pemerintah Pengganti Undang-Undang Nomor 1 Tahun 2014 Tentang Pemilihan Gubernur, Bupati, dan Walikota jo. Undang-Undang Nomor 8 Tahun 2015 Tentang Perubahan Atas UndangUndang Nomor 1 Tahun 2015 Tentang Penetapan Peraturan Pemerintah
Pengganti Undang-Undang Nomor 1 Tahun 2014 Tentang Pemilihan Gubernur, Bupati, dan Walikota Menjadi Undang-Undang jo. UndangUndang Nomor 10 Tahun 2016 Tentang Perubahan Kedua Atas Undang-Undang Nomor 1 Tahun 2015 Tentang Penetapan Peraturan Pemerintah Pengganti Undang-Undang Nomor 1 Tahun 2014 Tentang Pemilihan Gubernur, Bupati, dan Walikota, maka Kepala Daerah dipilih secara langsung oleh rakyat. Itu sebagaimana tercantum dalam Pasal 1 angka 1 Undang-Undang Nomor 8 Tahun 2015 bahwa yang dimaksud dengan Pemilihan Gubernur dan Wakil Gubernur, Bupati dan Wakil Bupati, serta Walikota dan Wakil Walikota yang selanjutnya disebut Pemilihan adalah pelaksanaan kedaulatan rakyat di wilayah Provinsi dan Kabupaten/Kota untuk memilih Gubernur dan Wakil Gubernur, Bupati dan Wakil Bupati, serta Walikota dan Wakil Walikota secara langsung dan demokratis. Berdasarkan ketentuan tersebut, Pilkada akhirnya harus dilaksanakan secara langsung.

Tiga tahun terakhir ini, Pilkada dilaksanakan secara serentak di seluruh wilayah Indonesia. Pilkada serentak 
Asnawi dan Aji Mulyana

Jurnal Hukum Mimbar Justitia

Vol. 4 No. 2 - Desember 2018

tahap pertama telah dilaksanakan di 8 Provinsi, 170 Kabupaten dan 26 Kota di Indonesia pada 9 Desember 2015 berpedoman dengan Undang-Undang Nomor 8 Tahun 2015 Tentang Perubahan Atas Undang-Undang Nomor 1 Tahun 2015 Tentang Penetapan Peraturan Pemerintah Pengganti Undang-Undang Nomor 1 Tahun 2014 Tentang Pemilihan Gubernur, Bupati, dan Walikota Menjadi Undang-Undang. Pada Pilkada serentak berikutnya terjadi perubahan terhadap Undang-Undang Nomor 8 Tahun 2015 yaitu menjadi UndangUndang Nomor 10 Tahun 2016, Pilkada Serentak tahap kedua dilaksanakan di 7 Provinsi, 18 Kota, dan 76 Kabupaten juga telah terlaksana pada 15 Februari 2017. Pada tahun 2018, Pilkada masih akan dilaksanakan lagi, Pemilihan Gubernur dan Wakil Gubernur untuk 17 Provinsi, Pemilihan Bupati dan Wakil Bupati di 115 Kabupaten, dan Pemilihan Walikota dan Wakil Walikota di 39 Kota.

Salah satu wilayah yang melaksanakan Pilkada Serentak di tahun 2017 adalah Provinsi Banten. Terdapat dua pasangan calon Gubernur dan Wakil Gubernur yang mendaftar pada
Pemilihan Gubernur yaitu Calon petahana, Rano Karno mencalonkan diri bersama Embay Mulya Syarief dengan didukung oleh PDI-Perjuangan, Partai Nasional Demokrat (Nasdem), dan Partai Persatuan Pembangunan (PPP). Pasangan calon lainnya yaitu Wahidin Halim didampingi oleh Andika Hazrumy. Pasangan ini diusung Partai Golongan Karya (Golkar), Partai Demokrat, Partai Kebangkitan Bangsa (PKB), Partai Hati Nurani Rakyat (Hanura), Partai Gerindra, Partai Keadilan Sejahtera, dan Partai Amanat Nasional. Pilgub Banten 2017 dimenangkan oleh pasangan

Wahidin Halim-Andika dengan perolehan suara 50,93\%, dan Pasangan Rano-Embay memperoleh suara 49,07\% (KPU-Banten).

Pilkada di Indonesia masih kental dibersamai politik uang (money politic). Membagi-bagikan uang maupun barang pada calon pemilih untuk memengaruhi keputusan masyarakat agar memilih calon kepala daerah tersebut dalam pemilu, praktek politik uang merupakan praktek yang sangat bertentangan dengan nilai demokrasi. Praktek politik uang ini telah hadir dari zaman orde baru tetapi sampai saat ini masih banyak 
Asnawi dan Aji Mulyana

Jurnal Hukum Mimbar Justitia

Vol. 4 No. 2 - Desember 2018

hambatan untuk menciptakan sistem pemilihan yang benar-benar bersih anti politik uang. Praktek politik uang ini sungguh misterius karena sulitnya mencari data untuk membuktikan sumber praktek tersebut. Namun ironisnya praktek politik uang ini sudah menjadi kebiasaan dan rahasia umum di masyarakat, bahkan para pemilih justru menantikan datangnya pemberian dari calon kepala daerah atau team suksesnya. ${ }^{4}$

Sistem demokrasi pemilihan kepala daerah di Indonesia masih harus banyak perbaikan, masih jauh dari harapan sistem pemilihan yang demokratis jujur dan adil. Hambatan terbesar dalam pelaksanaan yaitu masih tertanamnya budaya politik uang dimasyarakat. Banyak muncul kasuskasus masalah dalam pemilihan calon kepala daerah yang dibawa dan diputuskan kasusnya melalui lembaga peradilan Mahkamah Konstitusi (MK) karena pelanggaran nilai demokrasi dan

4 Asnawi, 2015, Penegakan Hukum Tindak Pidana Politik Uang Pemilihan Umum Legistatif Pada Masa Kampanye di Kabupaten Serang Menurut UndangUndang Nomor 8 Tahun 2012 Tentang Pemilihan Umum Anggota DPR, DPD dan $D P R D$, Serang, Tesis, Program Studi Ilmu Hukum UNTIRTA, hIm. 11. tujuan pemilihan calon anggota legislatif secara jujur dan adil masih banyak hambatan dan pelanggaran. Hal itu membuktikan betapa terpuruknya sistem pemilu di Indonesia yang memerlukan penanganan yang lebih serius. Masyarakat yang kondisi ekonominya masih banyak kekurangan dan kesulitan, pengetahuan pendidikan politiknya masih awam akan mejadi sasaran empuk para pelaku praktek poliik uang (money politic).

Pelanggaran Pilkada politik uang (money Politic) yang dilakukan calon kepala daerah hampir di semua daerah. Berdasarkan data Bawaslu pada Pilkada serentak 2017 ditemukan pelaksanaan politik uang pada saat pencoblosan diantaranya di DKI Jakarta 8 temuan, Bangka Belitung 7 temuan dan Banten 5 temuan. $^{5}$ Kejahatan kecurangan dan pelanggaran politik uang (money Politic) pada masyarakat merupakan tindakan kejahan pidana bertentangan dengan dengan undang-undang Pilkada maupun dengan KUHP, hal tesebut perlu peneggakan dan kepastian hukum dimasyarakat agar perbuat-perbuatan yang dilakuan partai politik ataupun

5 Detik News, Kamis, 16 Februari 2017. Diunduh pada 1 Mei 2018. 
Asnawi dan Aji Mulyana

Jurnal Hukum Mimbar Justitia

Vol. 4 No. 2 - Desember 2018

calon kepala daerah dapat diberikan sanksi pidana.

Dari latar belakang masalah yang telah diuraikan di atas, maka teridentifikasi Masalah sebagai berikut 1) Bagaimana Penegakan Hukum terhadap tindak pidana politik uang (money politic) sebagai tindak pidana pemilihan kepala daerah yang memenuhi aspek kepastian hukum?; 2) Bagaimana jenis dan bentuk perbuatan yang dapat dikualifikasi sebagai tindak pidana politik uang di Provinsi Banten?

\section{METODE PENELITIAN}

Metode pendekatan penelitian menggunakan yuridis normatif dan yuridis empiris. Maka untuk menunjang metode tersebut dengan upaya mencari data sekunder yang diperlukan dalam penelitian adalah metode studi atau penelitian kepus-takaan, yaitu dengan menginventarisasi data-data sekunder (library research) untuk kemudian dilakukan analisis kualitatif terhadap data-data tersebut. Data yang digunakan dalam penulisan ini adalah data sekunder. Data-data sekunder dalam penulisan ini meliputi: Bahan hukum primer, yaitu bahan-bahan hukum yang mengikat, dengan penelitian dilakukan di Badan Pengawas Pemilihan Umum Provinsi Banten mulai pada tanggal 1 Juni 2018.

\section{HASIL PENELITIAN DAN} ANALISIS

\section{A. Penegakan Hukum terhadap Tindak Pidana Politik Uang yang Memenuhi Aspek Kepastian Hukum.}

Kebijakan Hukum Pidana pada hakikatnya mengandung kebijakan mengatur mengalokasi dan membatasi kekuasaan, baik kekuasaan kewenangan warga masyarakat pada umumnya, untuk bertindak bertingkah laku dalam pergaulan masyarakat maupun

kekuasaan atau kewenangan penguasa penegak hukum. Dilihat dari aspek hukum pidana yang demikian, maka dapat dikatakan bahwa masalah dasar hukum pidana terletak di luar bidang hukum pidana itu sendiri, yaitu di bidang Hukum Tata Negara ${ }^{6}$.

6 Barda Nawawi Arief, 2006, Bunga Rampai Kebijakan Hukum Pidana, Citra Aditya Bakti, Bandung, hlm. 131. Dikutip dalam Asnawi, 2016, Penegakan Hukum Tindak Pidana Politik Uang Pemilihan Umum Legislatif Pada Masa Kampanye Di Kabupaten Serang, Jurnal Mimbar Hukum Justitia Fakultas Hukum Universitas Suryakancana, Vol. 2 No. 2 Desember, hlm. 772. 


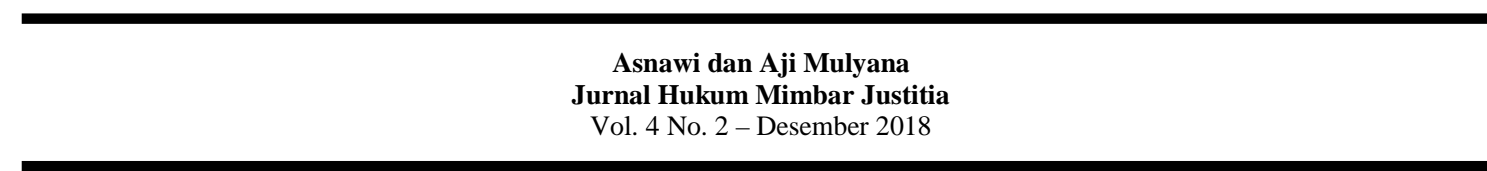

Dalam pelanggaran politik uang secara konseptual atau teoritis maupun secara yuridis formal peraturan perundang-undangan Indonesia tidak memberikan definisi atau pengertian tentang apa yang dikatakan dengan istilah Politik Uang. Namun demikian, berdasarkan unsur-unsurnya dapat ditujukkan ketentuan pasal-pasal yang dianggap membuat rumusan tindak pidana politik uang dalam pidana umum, tindak pidana politik uang dapat dikelopokan ke dalam tindakan penyuapan dan gratifikasi.

Secara yuridis formal ketentuan yang sering dianggap sebagai norma politik uang ditentukan dalam UndangUndang Nomor 10 Tahun 2016 tentang Pemilihan Gubernur, Bupati dan Walikota Pasal 187A.

(1) Setiap orang yang dengan sengaja melakukan perbuatan melawan hukum menjanjikan atau memberikan uang atau materi lainnya sebagai imbalan kepada warga negara Indonesia baik secara langsung ataupun tidak langsung untuk mempengaruhi Pemilih agar tidak menggunakan hak pilih, menggunakan hak pilih dengancara tertentu sehingga suara menjadi tidak sah, memilih calon tertentu, atau tidak memilih calon tertentu sebagaimana yang dimaksud dalam pasal 73 (4) dipidana dengan pidana penjara paling singkat 36 (tiga puluh enam bulan) dan paling lama 72 (tujuh puluh dua bulan) denda paling sedikit $\mathrm{Rp} 200.000 .000$ (dua ratus juta rupiah) dan paling banyak Rp1.000.000.000 (satu milyar rupiah).

(2) Pidana yang sama diterapkan kepada pemilih yang dengan sengaja melakukan perbuatan melawan hukum menerima pemberian atau janji sebagaimana dimaksud pada ayat (1).

Dari Pasal 187A telah jelas mengatur bahwa setiap orang, siapa pun itu baik calon kepala daerah yang bersangkutan, tim sukses, anggota partai politik atau siapa pun yang melakukan pelanggaran tindak pidana politik uang (money politic) dengan sengaja melakukan dan memberikan imbalan uang dan materi lainnya dikenakan sangsi pidana berdasakan pelanggaran yang dilakukan. Pasal tersebut juga mengancam kepada para pemilih yang dengan sengaja menerima pemberian baik uang atau barang maupun janji.

Perlunya kepastian penegakan hukum merupakan salah satu tujuan untuk menciptakan ketertiban, keamanan, dan ketentraman dalam masyarakat. Jika dalam negara terjadi tindak pidana, maka langkah yang harus diambil adalah penegakan hukum 
Asnawi dan Aji Mulyana

Jurnal Hukum Mimbar Justitia

Vol. 4 No. 2 - Desember 2018

pidana dengan menindak pelakunya sesuai dengan peratuaran perundangundangan yang berlaku dalam hukum pidana maupun dalam undang-undang Pilkada, untuk itu sebelum terjadi suatu tindak pidana pelangaran Pilkada dilakukan pencegahan.

Fungsi hukum Pidana sebagai hukum positif adalah untuk melindungi masyarakat dalam pergaulan agar tidak terjadi kekacauan. Tujuan hukum menurut Subekti menyatakan melayani tujuan Negara tersebut dengan menyelenggarakan keadilan dan ketertiban syarat-syarat yang pokok untuk mendatangkan kemakmuran dan kebahagiaan bahwa keadilan itu kiranya dapat digambarkan sebagai suatu keadaan keseimbangan yang membawa ketentraman didalam hati orang, dan jika diusik atau dilanggar akan menimbulkan kegelisahan dan kegoncangan. $^{7}$

Muladi menyatakan tehadap kebijakan hukum pidana secara universal diakui bahwa terdapat hubungan antara kejahatan dan kebutuhan untuk meningkatkan

7 Kansil, 1989, Pengantar Ilmu Hukum dan Tata Hukum Indoeesia, Balai Pustaka, Jakarta, hlm. 41. berbagai kondisi sosial dan untuk mendorong pembangunan kebijakan sosial (social politcy) yang akan menunjang kejahatan. ${ }^{8}$

Berdasarkan Indeks Kerawanan Pemilukada (IKP) 2017 yang dikeluarkan Badan Pengawas Pemilu (Bawaslu) sebelum dilaksanakannya pemilihan kepala daerah, Banten adalah salah satu daerah yang memiliki kerawanan tinggi bahkan masuk kedalam Tiga besar daerah yang memiliki kerawanan tertinggi setelah Papua Barat dan Aceh. Dalam penyelenggarakan Pilkada Gubernur Banten, aspek kontestasi masih menjadi dimensi kerawanan paling tinggi yang disebabkan hubungan kekerabatan antar calon kepala daerah. Selain itu, dalam Pilkada di Banten kental dengan nuansa fenomena politik dinasti, yang dapat mengganggu jalannya Pilkada serentak yang Jurdil dan bersih. Pandangan itu dilatar belakangi banyaknya jejaring kerabat calon di lingkungan birokrasi pemerintahan yang berperan untuk mensukseskan pencalonan kandidat tersebut, dengan memobilisasi jalur birokrasi.

8 Muladi, 2009, Hak Asasi Manusia, Refika Aditama, Bandung, hlm. 140. 
Tugas dan wewenang Panwas

Kabupaten/Kota dalam Pengawasan

Penyelenggaraan Pemilihan berdasarkan

Pasal 30 Undang-Undang Nomor 10

Tahun 2016 meliputi:

a. Mengawasi

tahapan

penyelenggaran pemilihan yang meliputi:

1. Pelaksanaan pengawasan rekrutmen PPK, PPS, dan KPPS;

2. Pemuntahiran data pemilih berdasarkan data kependudukan dan penetapan Daftar Pemilih Sementara dan Daftar Pemilih Tetap;

3. Pencalonan yang berkaitan dengan persyaratan dan tata cara pencalonan;

4. Proses dan penetapan calon;

5. Pelaksanaan kampanye;

6. Pelengkapan pemilihan dan pendistribusiannya;

7. Pelaksanaan pemungutan suara dan proses penghitungan suara hasil pemilihan;

8. Pelaksanaan pengawasan pendaftaran pemilih;
9. Mengendalikan pengawasan seluruh proses perhitungan suara;

10. Penyampaian surat suara dari tingkat TPS sampai ke PPK;

11. Proses rekapitulasi suara yang dilakukan oleh KPU Provinsi, Kabupaten, dan Kota dari seluruh Kecamatan;

12. Pelaksanaan penghitungan dan pemungutan suara ulang, Pemilu lanjutan, dan pemilu susulan; dan

13. Proses pelaksanaan penetapan hasil Pemilihan Bupati dan Wakil Bupati serta Walikota dan Wakil Walikota.

b. Menerima laporan dugaan pelanggaran terhadap tahapan pelaksanaan peraturan perundangundangan mengenai Pemilihan.

c. Menyelesaikan temuan dan laporan pelanggaran Pemilihan dan sengketa pemilihan yang tidak mengandung unsur tindak pidana;

d. Menyampaikan temuan dan laporan kepada KPU Provinsi dan 
Asnawi dan Aji Mulyana

Jurnal Hukum Mimbar Justitia

Vol. 4 No. 2 - Desember 2018

KPU Kabupaten/Kota untuk ditindaklanjuti;

e. Menyampaikan temuan dan laporan yang bukan menjadi kewenangannya kepada instansi yang berwenang;

f. Meyampaikan laporan kepada Bawaslu sebagai dasr untuk mengeluarkan rekomendasi Bawaslu yang berkaitan dengan adanya dugaan tindakan yang mengakibatkan terganggunya tahapan Penyelenggara Pemilihan oleh penyelenggara di Provinsi, Kabupaten dan Kota;

g. Mengawasi pelaksanaan tindak lanjut rekomendasi Bawaslu tentang pengenaan sanksi kepada anggota KPU Provinsi dan KPU Kabupaten/Kota, sekretaris dan pegawai sekretariat KPU Provinsi dan KPU Kabupaten/Kota yang terbukti melakukan tindakan yang mengakibatkan terganggunya tahapan penyelenggaraan Pemilihan yang sedang berlangsung;
h. Mengawasi
pelaksanaan sosialisasi penyelenggaraan pemilihan; dan

i. Melaksanakan tugas dan weweang lain yang diberika oleh peraturan perundang-undangan.

Sebagaimana yang disebutkan dalam tugas dan fungsi panitia pengawas pemilihan kepala daerah untuk menciptakan ketetiban dan keamanan dalam melaksanakan pemilihan, bila terjadinya pelangaran baik dalam masa kampanye, masa tenang, dan pemilihan panwas harus bertindak memberikan teguran dan memproses pelenggaran bila cukup bukti pelanggaran tindak pidana panwas wajib melaporkan ke Polisi agar diproses lebih lanjut sesuai aturan hukum.

Berdasarkan data yang di peroleh dari Kepala Sekretariat Badan Pengawas Pemilihan Umum (Bawaslu) Provinsi Banten terdapat 103 pelangaran pemilu Kepala Daerah Gubernur Dan Wakil Gubernur. 
Asnawi dan Aji Mulyana

Jurnal Hukum Mimbar Justitia

Vol. 4 No. 2 - Desember 2018

Berikut Tabel Pelanggaran Pemilu Kepala Daerah Gubernur dan Wakil Gubernur Provinsi Banten Tahun 2017:

\begin{tabular}{|c|c|c|}
\hline No & Pelanggaran & Banyaknya Kasus \\
\hline 1. & Keterlibatan Pejabat Negara & 8 \\
\hline $2 .$. & Netralisasi ASN & 10 \\
\hline 3. & Keterlibatan Anak di Bawah Umur & 8 \\
\hline 4. & Politik Uang & 2 \\
\hline 5. & Administrasi & 30 \\
\hline 6. & Penyalahgunaan Anggaran & 27 \\
\hline 7. & Penyalahgunaan Alat Praga Kampanye & 1 \\
\hline 8. & Kampanye Terselubung & 3 \\
\hline 9. & Penggunaan Sarana Ibadah & 5 \\
\hline 10. & Penggunaan Fasilitas dan anggaran Pemerintah & 103 \\
\hline 11. & dan Pemerintah Daerah & \\
\hline & Kecurangan Saat Pemilihan di TPS & \\
\hline
\end{tabular}

Pelanggaran itu meliputi keterlibatan Pejabat Negara yang tidak mengantungi izin yaitu sebanyak 8 kasus, Netralitas ASN (Aparatur Sipil Negara) sebanyak 8 kasus, Keterlibatan anak di bawah umur 1 kasus, Politik Uang sebanyak 10 Kasus, Administrasi sebanyak 8 kasus, Penyalahgunaan anggaran 2 kasus, Penggunaan Alat Praga Kampanye sebanyak 30 kasus, Kampanye terselubung sebanyak 27 kasus, penggunaan sarana ibadah 1 kasus, Penggunaan Fasilitas dan anggaran pemerintah dan pemerintah daerah sebanyak 3 kasus, dan Kecurangan saat Pemilihan di TPS sebanyak 5 kasus. ${ }^{9}$ (Sumber Bawaslu Provinsi Banten Tahun 2017)

Data tersebut belum termasuk kasus yang terjadi pada saat masa tenang yaitu pada tanggal 13 Februari, terdapat kasus politik uang berupa penyebaran paket sembako yang terjadi

\footnotetext{
BAWASLU Provinsi Banten, 2017, Rekapitulasi Penanganan Dugaan Pelanggaran Pemilihan Gubernur dan Wakil Gubernur Provinsi Banten.
} 
di Perumahan Bumi Ciruas Permai (BCP), Kecamatan Ciruas, Kabupaten Serang. Dimana dalam kasus tersebut terdapat dua orang terdakwa yang telah dinyatakan bersalah melanggar pasal 187A, dengan vonis tiga tahun penjara dan denda Rp 200.000.000. Namun terdapat hal yang menarik dalam kasus tersebut, bahwa keduanya hanyalah perantara untuk memberikan paket sembako itu kepada pemillih. Mereka mendapatkan pendistribusian paket sembako itu dari orang lain. Dua orang mendistribusikan ini sempat menjadi Daftar Pencarian Orang (DPO), namun keduanya tak dapat dijerat lantaran status keduanya hangus karena dalam dua pekan pengusutan tidak dapat ditangkap. Artinya, terdapat aktor intelektual yang bermain dibelakangnya yang belum bisa terusut.

Pelanggaran pelaksanaan Pilkada yang bersifat sistematis, terstruktur dan masif dapat menggugurkan pasangan calon peserta pemilu. Hal ini kemudian yang harus dibuktikan apakah pelaksanaan pelanggaran pilkada terjadi secara sitematis, terstruktur dan masif. Juga belum optimalnya penanganan pelanggaran politik uang juga masih menjadi permasalahan.
Pelanggaran-pelanggaran tindak pidana dalam pemilihan umum kepala daerah, Gubernur, Bupati dan Walikota disebabkan karena rendahnyan pengetahuan dan indisipiliner para peserta Pilkada, team sukses, kader partai dan penyelenggaranya itu sendiri, juga disebabkan kurang sosialisasi kepada pemilih. Rendahnya moralitas penegakan hukum, lemahnya penegakan hukum, kelemahan dalam penegakan hukum juga bisa terjadi karena lemahnya disiplin para peserta Pilkada, team sukses, kader partai dan juga penyelenggaraan pemilu serta termasuk rendahnya disiplin aparat penegak hukum.

\section{B. Jenis dan Bentuk Perbuatan Yang Dapat Dikualifikasi Sebagai Tindak Pidana Politik Uang di Provinsi Banten.}

Bentuk perbuatan yang dapat digolongkan pelangaran tindak pidana politik uang dalam pelaksanakan pilkada dapat dikualifikasi sebagai berikut: a) memberikan sesuatu dalam bentuk barang atau uang, kepada kader Partai, Tim sukses, atau kelompok masyarakat tertentu. b) memberikan atau menjanjikan sumbangan barang atau uang untuk masyarakat sepseti 
Asnawi dan Aji Mulyana

Jurnal Hukum Mimbar Justitia

Vol. 4 No. 2 - Desember 2018

Pembangunan Jalan, Gang, Mesjid, Musollah, Pondok Pesantren, Majlis Taqlim dan lain-lainnya. c) membagibagikan uang atau barang bebentuk semako secara langsung dari rumah kerumah. d) Memberikan sumbangan berupa uang atau barang, berupa, perbaikan sarana prasarana olah raga, kaos seragam seperti bola voli, fudsal, basket dan lain-lain kepada perkumpulan-perkumpulan

kepemudaan, yang bertujuan agar para pemuda atau perkumpulan kepemudaan tersebut mendapatkan simpati dan mendukung kepada calon yang memberikan barang.

Dengan demikian sangat erat hubuangan politik dengan uang, jika sampai berkelanjutan tejadi politik uang sangat berbahya bagi rakyat dan pasangan calon lain. karena calon yang memiliki modal yang sangat besar sangat diuntungkan berapapun dana yang dibutuhkanakan ia keluarkan untuk digunakan atau dibagi-bagikan. Keuntungan yang ia peroleh jauh lebih besar karena pihak yang diuntungkan dalam peraktek politik uang pilkada adalah pihak pasangan calon pasangan cagub dan cawagub yang memiliki curag memiliki modal besar karena akan memmperoleh dukungan politik, adapun yang dirugikan rakyat, ketika calon pasangan cagub dan cawagub yang membagi-baikikan uang atau baranng jika terpilih. maka ia dalam membuat kebijakan-kebijakan akan mengambil suatu kesepmatan mencari keuntungan yang lebih besar dari pembuatan kebijakan tersebut karena ia telah meluarkan banyak uang dan ia bagaimana supaya uang yang sudah di keluarkan bisa kembali lagi.

Biasanya ada cara untuk melakukan pendekatan secara langsung maupun tidak langsung melalui pihak ketiga tim sukses atau kader partai pengsung untuk melakukan transaksi pemberian uang tunai, barang, atau janji-janji hal ini intinya adalah Politik uang bagai mana strategi cara memberikan Uang, hal ini bertentangan dengan undang-undang Pilkada pasal 187A, bahkan Hukum Pidana tidakan menyuap dan disuap.

\section{Mekanisme Penyelesaian}

Pelengaran Pidana Pemilihan Kepala Daerah.

Dalam proses penyelesaian pidana pilkada adalah proses penyidikan sebenarnya penanganan tidak pidana 
Asnawi dan Aji Mulyana

Jurnal Hukum Mimbar Justitia

Vol. 4 No. 2 - Desember 2018

pemilihan kepala daerah tidak berbeda penanganan dengan tindak pidana pada umumnya, melalui Bawaslu/Panwaslu, Kepolisian, Kejaksaan dan Pengadilan, secara umum perbuatan tidak pidana politik uang yang diatur dalam undangundang No 10 tahun 2016 tentang Pemilihan Gubernur, Bupati dan Walikota. juga terdapat dalam KUHP. Dan tata cara pennyelesaiannya juga mengacu pada KUHAP. dengan asas lex specialist derogate generalis maka aturan undang-undang Pilkada lebih utama. Apabila terdapat aturan yang sama maka ketentuan yang diatur KUHP dan KUHAP menjadi tidak berlaku.

Temuan pelangaran Pilkada dan laporan tentang dugaan pelanggaran pilkada yang mengandung unsur pidana, setelah dilakuka kajian dan didukung dengan data permulaan yang cukup, diteruskan Bawaslu kepada penyidik Kepolisian dalam jangka waktu 14 hari tersebut termasuk hari libur, hal ini mengacu pada KUHAP.

\section{PENUTUP}

Dalam penegakan terhadap Tindak Pidana Politik Uang pemilihan Kepala Daerah kurangnya pengawasan.
Pengawasan yang tidak profisional dalam menjaankan penegakaan hukum pada saat mulai dari masa kampanye sampai hari pelaksanaan pemilihan, kurangnya koordinnasi antara Bawaslu/Panwaslu dengan Kepolisian kurang berjalan dengan baik.

a. Secara yuridis formal ketentuan yang sering dianggap sebagai norma politik uang ditentukan dalam UndangUndang Nomor 10 Tahun 2016 tentang Pemilihan Gubernur, Bupati dan Walikota Pasal 187A. Sebagaimana yang disebutkan dalam tugas dan fungsi panitia pengawas pemilihan kepala daerah untuk menciptakan ketetiban dan keamanan dalam melaksanakan pemilihan, bila terjadinya pelangaran baik dalam masa kampanye, masa tenang, dan pemilihan panwas harus bertindak memberikan teguran dan memproses pelenggaran bila cukup bukti pelanggaran tindak pidana panwas wajib melaporkan ke polisi agar diproses lebih lanjut sesuai aturan hukum. Berdasarkan data yang di peroleh dari Kepala Sekretariat Badan Pengawas Pemilihan Umum (Bawaslu) Provinsi Banten terdapat 103 pelangaran pemilu Kepala Daerah Gubernur dan Wakil Gubernur Data 
Asnawi dan Aji Mulyana

Jurnal Hukum Mimbar Justitia

Vol. 4 No. 2 - Desember 2018

tersebut belum termasuk kasus yang terjadi pada saat masa tenang. ini menandakan lemah pengawasan dalam pemilihan Kepala Daerah.

b. Bentuk perbuatan yang dapat digolongkan pelangaran tindak pidana politik uang dalam pelaksanakan pilkada adalah sebagai berikut memberikan uang atau atau barang baik secara langsung maupun tidak langsung melalui pihak ketiga tim sukses atau kader parttai untuk mebagibaikan sesuatu berupa, uang tunai, sembako, perbaikann Jalan, gang, Mesjid, Musohla, majlis Taqlim atau menjanjikan sesuatu, hal ini dapat di golongkan suatu pelangaran tidak pidana politik uang sesuai dengan ketentuan Undang-Undang Nomor 10 Tahun 2016 tentang Pemilihan Gubernur, Bupati dan Walikota Pasal $187 \mathrm{~A}$

\section{DAFTAR ISI}

\section{A. Buku}

Barda Nawawi Arief, 2006, Bunga Rampai Kebijakan Hukum Pidana, Citra Aditya Bakti, Bandung.

Kansil, 1989, Pengantar Ilmu Hukum dan Tata Hukum Indoeesia, Balai Pustaka, Jakarta.
Martitah, 2013, Mahkamah Konstitusi (Dari Negative Legislature ke Positive Legislature), Konstitusi Press (Konpress), Jakarta.

Muladi, 2009, Hak Asasi Manusia, Refika Aditama, Bandung.

Rozali Abdullah, 2005, Pelaksanaan Otonomi Luas dengan Pemilihan Kepala Daerah Secara Langsung, Rajawali Pers, Jakarta.

\section{B. Peraturan \\ Perundang- Undangan}

Undang-Undang Dasar Republik Indonesia Tahun 1945.

Undang-Undang Nomor 1 Tahun 1946 Tentang Kitab Undang-Undang Hukum Pidana.

Undang-Undang Nomor 8 Tahun 1981 Tentang Kitab Undang-Undang Hukum Acara Pidana.

Undang-Undang Nomor 32 Tahun 2004 tentang Pemerintahan Daerah yang telah diubah dengan Undang-Undang Nomor 23 Tahun 2014 tentang Pemerintahan Daerah.

Undang-Undang Nomor 22 Tahun 2007 yang telah diubah dengan Undang-Undang Nomor 15 Tahun 2011 Tentang Penyelenggaraan Pemilihan Umum.

Undang-Undang Nomor 1 Tahun 2015 Tentang Penetapan Peraturan Pemerintah Pengganti UndangUndang Nomor 1 Tahun 2014 Tentang Pemilihan Gubernur, Bupati, dan Walikota, 
Asnawi dan Aji Mulyana

Jurnal Hukum Mimbar Justitia

Vol. 4 No. 2 - Desember 2018

sebagaimana telah diubah dengan Undang-Undang Nomor 8 Tahun 2015 Tentang Perubahan Atas Undang-Undang Nomor 1 Tahun 2015 Tentang Penetapan Peraturan Pemerintah Pengganti Undang-Undang Nomor 1 Tahun 2014 Tentang Pemilihan Gubernur, Bupati, dan Walikota Menjadi Undang-Undang jo. Undang-Undang Nomor 10 Tahun 2016 Tentang Perubahan Kedua Atas Undang-Undang Nomor 1 Tahun 2015 Tentang Penetapan Peraturan Pemerintah Pengganti Undang-Undang Nomor 1 Tahun 2014 Tentang Pemilihan Gubernur, Bupati, dan Walikota.

Undang-undang Nomor 2 Tahun 2008 tetang Partai politik, sebagaimana telah diubah dengan Undangundang Nomor 2 tahun 2011 tetang perubahan Undang-undang 2 tahun 2008 tentang Partai Politik.

Peraturan Komisi Pemilihan Umum Nomor 3 Tahun 2016 Tetang Tahapan, Program, dan Jadwal Penyelenggaraan Pemilihan Gubernur dan wakil Gubernur, Bupati dan Wakil Bupati dan/atau Walikota dan Wakil Walikota Tahun 2017.

Peraturan Komisi Pemilihan Umum Nomor 5 Tahun 2016 Tetang Perubahan Kedua Atas Peraturan Komisi Pemilihan Umum Nomor 9 Tahun 2015 tentang Pencalonan Pemilihan Gubernur dan wakil Gubernur, Bupati dan Wakil Bupati dan/atau Walikota dan Wakil Walikota.
Peraturan Komisi Pemilihan Umum Nomor 13 Tahun 2016 Tentang Perubahan Atas Peraturan Komisi Pemilihan Umum Nomor 8 Tahun 2015 Tentang Dana Kampanye Peserta Pemilihan Gubernur dan wakil Gubernur,Bupati dan Wakil Bupati dan/atau Walikota dan Wakil Walikota.

Peraturan Komisi Pemilihan Umum Nomor 11 Tahun 2016 Tentang Perubahan Atas Peraturan Komisi Pemilihan Umum Nomor 6 Tahun 2015 Tentang Norma, Standar, Prosedur, Kebutuhan Pengadaan dan Pendistribusian Perlengkapan Penyelenggaraan Pemilihan Gubernur dan wakil Gubernur, Bupati dan Wakil Bupati dan/atau Walikota dan Wakil Walikota.

C. Jurnal.

Asnawi, 2016, Penegakan Hukum Tindak Pidana Politik Uang Pemilihan Umum Legislatif Pada Masa Kampanye Di Kabupaten Serang, Jurnal Mimbar Hukum Justitia Fakultas Hukum Universitas Suryakancana, Vol. 2 No. 2 Desember.

Dedi Mulyadi dan M. Rendi Aridhayandi, 2015, Putusan Mahkamah Konstitusi Tentang Pemilu Serentak Dihubungkan Dengan Pencegahan Korupsi Politik, Jurnal Mimbar Hukum Justitia Fakultas Hukum Universitas Suryakancana, Vol. 1 No. 2 Desember.

D. Tesis, Internet dan Lain-lain. 
Asnawi dan Aji Mulyana

Jurnal Hukum Mimbar Justitia

Vol. 4 No. 2 - Desember 2018

Asnawi, 2015, Penegakan Hukum

Tindak Pidana Politik Uang

Pemilihan Umum Legistatif Pada

Masa Kampanye di Kabupaten

Serang Menurut Undang-Undang

Nomor 8 Tahun 2012 Tentang

Pemilihan Umum Anggota DPR,

$D P D$ dan DPRD, Serang, Tesis,

Program Studi Ilmu Hukum

UNTIRTA.
Detik News, Kamis, 16 Februari 2017. Diunduh pada 1 Mei 2018.

BAWASLU Provinsi Banten, 2017, Rekapitulasi Penanganan Dugaan Pelanggaran Pemilihan Gubernur dan Wakil Gubernur Provinsi Banten. 